\title{
Strategy Use Awareness in Academic Listening Practices Relative to L2 Motivation among Chinese Tertiary Students
}

\author{
Bixi Jin \\ Faculty of Education, University of Hong Kong, Hong Kong SAR, China \\ Wei Xu \\ Shanghai International Studies University, China
}

\begin{abstract}
Academic listening has been widely studied from the perspective of note-taking, attention to discourse markers, and schematic knowledge. Learner variables, such as motivation, degree of anxiety, and learner beliefs, have all received increasingly attention from researchers, but have not yet been sufficiently explored in second language (L2) listening. This paper investigates the correlations between second language learning motivation and learners' strategy use awareness in academic listening practices. Quantitative data was obtained using questionnaires issued to 79 second year English-major students after a TOEFL lecture listening practice. The results suggest that teacher classroom instruction and feedback, task significance, and learners' commitment encourage the listeners to apply more listening strategies. Pedagogical implications drawn from the results are discussed, concluding that $\mathrm{L} 2$ listening teachers should develop motivation-based strategy instruction with emphasis on creating a learner-centred constructivist learning environment. In addition, a skill-oriented approach is proposed in order to improve course design in L2 listening instruction. This would train students to consciously use strategies to improve their listening comprehension in an EFL ( English as a Foreign Language) context. Suggestions are provided at the end for future research.
\end{abstract}

Index Terms - L2 motivation, academic listening practices, listening strategies, motivation-based instruction

\section{INTRODUCTION}

Academic listening, also referred to as listening to lectures or academic discussion, is of great importance to advanced second language learners. According to Flowerdew (1994), special demands are placed upon listeners if they strive to succeed in academic listening, such as understanding relevant background knowledge, distinguishing important and unimportant information, and taking notes. Because of this, academic listening has long been considered as a difficult task for proficient language learners. However, few ESL (English as Second Language) or EFL students have received substantial instruction in listening to lectures either in listening or academic courses. This is particularly true in Chinese EFL instruction. Consequently, Chinese undergraduates who pursue further studies in major English-language speaking countries experience extreme difficulties in understanding academic lectures delivered by the native speakers (Ou, 1991). Huang $(2005,2006)$ conducted a series of systematic studies to examine Chinese overseas students' performances in this respect. According to her study, about $88 \%$ of the 78 Chinese students surveyed could understand $80 \%$ or more of the lectures given in their majors and a total of $92.3 \%$ of the participants reported having difficulties in understanding academic lectures and in taking notes.

As for research, even though Lynch (2010) argued that academic listening was an under-explored area of inquiry, research concerning L2 academic listening has been extensively carried out, however only narrowly in the aspects of rate and pace of lectures, micro- and macro discourse markers, lecture simplification and elaboration adjustments, (Flowerdew, 1994; Rost, 2002) and the effectiveness of note-taking and summarizing (Rost, 1990). Strategy use and instructions in academic listening still requires further investigation.

In the 1980s, relevant research suggested significant relationships between L2 motivation and choice of learning strategies (e.g., MacIntyre and Noel, 1996; Oxford and Nyikos, 1989). A large-scale investigation led by Oxford and Nyikos (1989) was conducted among 1,200 foreign language students studying at a US university. According to their report, among all the variables affecting choices of learning strategies (personalities, learning styles, attitudes, etc), "motivation is the single most powerful influence on the choice of language learning strategies" (p.294). MacIntyre and Noels (1996) carried out their research focusing on the correlations between strategy use (metacognitive, cognitive, and social strategies) and Gardner's social-psychological motivation theory. The results showed that highly motivated students were willing to invest effort and tended to use strategies more frequently. A few studies have subsequently been conducted in a Chinese EFL context. Xu (2011) investigated L2 motivation and learning strategies among 284 Chinese non-English major undergraduates. The results indicated that overall learning strategies and motivation were closely related to motivation, and strong correlations were particularly found between motivational strength (effort-making 
intention) and personal goals. Another study led by Yu (2012) was conducted among 164 students at a local Chinese university. Revised motivation questionnaires and learning strategy questionnaires adapted from Oxford (1990), O'Malley and Chamot (1999) were used. The findings suggested that both integrative and instrumental motivation led to the use of a variety of learning strategies. However, the author did not specify the components pertaining to "learning situation motivation", which could result in the correlations between learning situation motivation and use of strategies.

\section{LITERATURE REVIEW}

\section{A. Review of Research on Motivation Theory}

Over the past five decades, L2 motivation research within second language acquisition has undergone four main periods of development: social-psychological (1959-1990), cognitive-situated (during the 1990s), process-oriented (turn of the century), and social-dynamic (current) (Ushioda and Dörnyei, 2010). Through observing the language learning situation in Canada, an individual's attitude towards the L2 and the L2 community is viewed as an important factor in L2 learning behaviour (Gardner, 1972). Affective factors, for the first time, became the focal point in language learning research. In addition, interpretation of motivation from the social-psychological viewpoint led to the emergence of the concept of integrative motivation.

Many motivation studies have been carried out to explore the casual relationships between successful L2 learning and motivation. Seminal as Gardner's model was, it was criticized because it was "particularly sensitive to the social dimension of L2 motivation" (Dörnyei, 1994), and thus inapplicable to the foreign language classroom setting. A gradual trend towards a more situated analyses of L2 motivation appeared thereafter, in which mainstream cognitive theories were fully considered. Factors that were central to cognitive theory, e.g., self-efficacy, attribution, and intrinsic motivation were all incorporated into various theoretical frameworks. Later on, researchers found the necessity of describing the temporal organization of motivation or the motivational process itself. The perspective from trait motivation (a learner's general motivational orientation) to state motivation (a learner's situation-specific motivation) then fully developed during the process-oriented period. In this period, motivation was viewed as a process, consisting of pre-actional, actional and post-actional phases, in which various internal and contextual motivational influences were considered (Dörnyei, 2003). This process model was by far "the most elaborate attempt to delineate the temporal structure of L2 motivation" (Ushioda and Dörnyei, 2012). However, there are insufficiencies in the theoretically appealing process-oriented L2 motivation model. For instance, Dörnyei (2003) claimed that the model was difficult to test empirically in a classroom setting because of its ill-defined motivational phase.

What is missing from this area of research is a clear picture of defining motivation constructs in relation to classroom teaching and learning. Consequently, there is a dearth of pedagogical implications concerning how to motivate students in particular classroom learning activities. Dörnyei's (1994) three-level L2 motivation is comprehensive in categorizing motivation at the L2 learner level, language level, and learning situation level; particularly in subcategorizing motivation at the learning situation level into motivational components at teacher-specific, group-specific, and course-specific levels. However, few studies have been devoted to using this all-encompassed model in examining students' motivation in a classroom setting. Therefore, further research needs to be conducted to construct an L2 motivation model that will not only be beneficial to a L2 classroom, but also can be tested empirically, so as to offer further insights into how best to motivate learners in classroom learning activities.

\section{B. Review of Research on Listening Strategies}

L2 listening strategies remain a crucial thread in listening comprehension research and it becomes a gradually elaborated conceptual framework (see O'Malley and Chamot, 1990; Vandergrift, 2003). On the one hand, effectiveness of strategy instruction, in terms of what kind of strategies to teach and how to teach them (Rubin, 1994), was gradually recognized in improving listening proficiency (e.g. McGruddy, 1995); with the exception of Graham, Santos, and Vanderplank (2010) exploring the changes of strategy use in the absence of explicit strategy instruction.

On the other hand, a few studies were devoted to exploring learner variables in strategy use (Bacon, 1992; McGruddy, 1995). Without examining the learner variables clearly, researchers and teachers will not be able to "understand the nature of lecture comprehension" and "produce definitive findings" (Rost, 2002). Progress has been made since Rubin's (1994) earlier review summarizing learner variables, encompassing language proficiency, affect, memory, age, gender, background knowledge, processing skills, as well as learning disabilities in L1. Goh (1998) used retrospective verbal reports among 16 ESL learners with different language levels to investigate frequency and range of strategy and tactics used. The results showed that the proficient language learners used more strategies and tactics than the non-proficient ones. All of them tended to use more cognitive strategies, but proficient groups were also good at using them. Motivation seems to be another variable that is currently unexplored. Relationships between strategy use and motivation in academic listening are also not adequately investigated. Considered as a salient area of research in listening comprehension (Rost, 2002), Richards (1983) proposed a set of skills required for lecture listening. In his comprehensive list, a number of particular skills associated with lecture listening were identified, among which some fundamental skills were: (a) the ability to identify the purpose and scope of a lecture; (b) the ability to identify relationships among units within a discourse (e.g., major ideas, generalizations, hypotheses, supporting ideas, examples); (c) the ability to identify the role of discourse markers in signalling the structure of a lecture (e.g., conjunctions, adverbs, 
gambits, routines); (d) the ability to recognize key lexical items related to a subject/topic; (e) the ability to deduce meanings of words from the context; (f) the ability to identify the topic of a lecture and follow the topic development; and (g) the ability to infer relationships (e.g., cause, effect, conclusion). In this study, the categories of academic listening strategies were constructed based on the micro-skills identified in Richards's work as well as O'Malley and Chamot's (1990) theoretical model of learning strategies, i.e., metacognitive strategy, cognitive strategy, and social-affective strategy (details of their model can be found in Section 3.2.3).

\section{Review of Research on the Relationships between Learners'Motivation and Listening Comprehension Strategies}

Vandergrift's (2005) study in investigating motivation and strategy use in L2 listening was representative in this area of inquiry. He pinpointed the relationships between motivation and metacognitive strategies in L2 listening comprehension among 57 French learners. They came from Canadian junior high schools using French as their second language. Vandergrift used Deci and Ryan's self-determination theory-based questionnaire to examine students' three motivation orientations: amotivation, intrinsic, and extrinsic. Moreover, a Metacognitive Awareness Listening Questionnaire (MALQ) based upon L2 listening theory validated by Vandergrift was used. The material they listened to was a number of authentic conversations with 28 multiple-choice comprehension questions needed to be completed within regular classroom time. The data showed that intrinsically-motivated students preferred to use metacognitive strategies frequently such as maintaining concentration, knowing where to focus attention, evaluation of comprehension. When learners were extrinsic-oriented, the strategies used were the same, but relationships were less significant. Lastly, most of the metacognitive strategies correlated negatively with a motivation. The study suggested that students who were strongly motivated, regardless of extrinsic or intrinsic motivation, used listening strategies that were more "metacognitive in nature" (Vandergrift, 2005, p.196).

Recently, a study led by Onoda (2012) examined how self-regulation strategies, peer learning strategies, and effort regulation strategies were associated with two motivational variables: goal-orientation and self-efficacy. Onada's listening comprehension practices included 39 items covering several long passages in different topics (e.g., school events, sightseeing). The results of this study suggested that goal orientation and self-efficacy affected effort regulation strategies as well as the self-regulation and peer learning strategies.

\section{Gaps in the Existing Literature}

The overview of research reveals that several gaps which can be identified. Firstly, it has been found that insufficient attention has been paid to explore classroom-based language learning motivation on the basis of Dornyei's 1994 study. In addition, with regard to the research on motivation and L2 listening practices, these are mainly devoted to exploring the relationships between metacognitive strategies and L2 motivation. Research should go in-depth into a wide range of listening strategies, not only limited to metacognitive strategies. Therefore, the present study seeks to explore language listeners' strategy use awareness relative to L2 motivation with the aim of providing language teachers with important insights into how L2 motivation can be integrated into strategy training in academic listening practices.

\section{METHOD}

\section{A. Participants}

This study consisted of a questionnaire survey, aimed at investigating students' language learning motivation in classroom and the use of L2 listening strategy. The survey was conducted with 79 second-year English major students enrolled in a L2 listening course at the School of Education at a university in Shanghai. At the very beginning the session, the research made clear that participation had nothing to do with their final scores on the course, but based solely on their willingness to be involved in the research.

The majority of the respondents were female students. Approximately 50 students began to learn English over 10 years, while the other students' learning experience varied from between 5 to 10 years. Students' listening proficiency levels remained upper-intermediate based upon their reports of previous final listening examinations. Almost half of the students achieved over $80 \%$ in the exam, 16 students achieved at least $70 \%$, and 10 students achieved $90 \%$. According to the course instructor, the listening test mainly tested the students' comprehension ability through various types of material; for instance, news, long conversations, long passage listening, lecture listening, and sentence or spot dictation. The question format included multiple-choice, blank-filling, and true or false question. Additionally, from their previous learning experience, students were trained to listen to lectures mainly in the form of relevant TOEFL listening practices at the beginning of their second year listening courses.

\section{B. Instrumentation}

The students were asked to complete the questionnaire (written in Chinese) after they had finished a lecture listening practice. A four-point Likert scale was adopted for the study. On a scale ranging from 1 to 4 (strongly disagree, disagree, agree, strongly agree) participants rated the extent to which the statements in the questionnaire can indicate their preference. The higher on the scale indicated the strongest agreement with the statement, while the lower on the scale indicated the least agreement.

In order for their presence to not adversely affect the responses of the students the researcher adopted a non-intrusive 
manner while conducting the survey by remaining silent in the classroom during listening practice. The following are the instruments used in the data elicitation.

1. Listening Practice Test

The materials used in this study consisted of 20 items in total, covering 8 motivational and 12 academic listening strategy items. The test was selected from a TOEFL lecturer listening practice with a particular focus on the topic of public health. Multiple choice and filling in the blanks were the main question format. The purpose was to examine the students' execution of the strategies such as predicting the topic, planning strategies in advance, and using selective attention while answering the questions.

2. L2 motivation Elicitation Questionnaire

There were 8 items in motivation questionnaire (see Table 1). The theoretical framework underpinning the L2 motivation questionnaire was derived from Dornyei's (1994) three-level L2 language learning motivation, with particular reference to learner and learning situation level, as the L2 motivation discussed here is learning-context specific. Unfortunately, the investigation of language level (i.e., integrative and instrumental motivation) is beyond the scope of this study. The selection and adaptation of the 8 items for the present study were generally in line with motivation at learner and learning situation level. They also fell neatly into the following four major areas: (a) learning task novelty (M6), which concerns how a learner evaluates the learning stimuli (i.e., learning task) he/she receives which then leads to an emotional, and consequently a behavioural response; (b) coping potential (M7, M8), consists of self-efficacy and attribution, the former is defined as a personal judgment of one's own ability in a specific action, whist the latter refers to a past failure or success that is ascribed to one's ability (task difficulty may affect one's performance in certain learning performance); (c) task significance (M9), which refers to motivation derived from a learner's own perception towards the various external influences that are personal and relevant and considered desirable to them; and (d) learning situation (M10, M11) constitutes a teacher's way of presenting and implementing a task, giving feedback, and creating a learning environment.

TABLE 1

ITEMS IN THE L2 MOTIVATION QUESTIONNAIRE

\begin{tabular}{ll}
\hline Items & Classroom-based motivation constructs \\
\hline M6 & The topic in this practice is novel to me and I enjoy practicing it. \\
M7 & I did not perform well in the previous lecture comprehension practice, so I feel I will not perform well this time. \\
M8 & I did not know how to cope with this practice because of fast speaking rate, substantial information, and so on. \\
M9 & I tried to invest this practice with personal significance. \\
M10 & The learning environment in the L2 listening course is not desirable and interactive. \\
M11 & I was motivated when I found the teacher gave detailed instructions and explanations in the pre-listening stage (e.g. \\
n12 & new word, listening strategy instruction, necessary background information, etc). \\
M13 & The teacher's feedback and comments made me confident in lecture comprehension. \\
& I made effort to use skills and tactics in this practice in order to improve my comprehension. \\
M9=task significance; M10=learning environment; M11=teacher instruction; \\
M12=teacher feedback; M13=commitment to task
\end{tabular}

3. Academic Listening Strategies Elicitation

The listening strategies questionnaire (see Tables 2 and 3) was developed by adapting O'Malley and Chamot's (1990) categorization of listening strategies, and also by incorporating Richards's (1983) comprehensive summary of academic listening skills mentioned in the review of literature.

Metacognitive strategies include four subsets: planning, selective attention, self-monitoring, and self-evaluation. Cognitive strategies consist of elaboration, note-taking, summarization, and inference. Affective strategies are made up of self-encouragement and interaction after class. Detailed descriptions of the listening strategies and items in the questionnaires are presented in Tables 2 and 3.

TABLE 2

TAXONOMY OF ACADEMIC LISTENING STRATEGIES

\begin{tabular}{ll}
\hline Listening Strategies & Descriptions \\
\hline Metacognitive Strategies & Planning: Predicting topic and would-be used strategies. \\
& Selective attention: Identifying discourse markers and key lexical terms related to topic. \\
& Self-monitoring: Monitoring comprehension during the process of listening. \\
& Self-evaluation: Judging one's overall strategy use after listening. \\
\hline Cognitive Strategies & Elaboration: Making use of schematic knowledge to assist comprehension. \\
& Note-taking: Retaining information through note-taking in a organized and hierarchical way. \\
& Summarization: Making a mental or written summary about information heard so far. \\
& Inference: Deducing meanings of unfamiliar words (e.g., technical terms) from context; infer \\
& relationships between information. \\
\hline Affective Strategies & Self-encouragement: Encouraging oneself to cope with expected/unexpected difficulties. \\
& After-class interaction: Interacting with teachers or peers to address queries. \\
\hline
\end{tabular}


TABLE 3

ITEMS IN ACADEMIC LISTENING STRATEGIES QUESTIONNAIRE

\begin{tabular}{ll}
\hline Items & Academic listening strategies \\
\hline ME1 & I remind myself of paying attention to discourse markers (but, next, firstly etc.), and important concepts. \\
ME2 & I planned a series of lecture-related strategies (e.g. note-taking, selective attention) before I listened. \\
ME3 & As I listen, I am ready to monitor my comprehension. \\
ME4 & After listening, I think back to the details of how I listened and the execution of the strategy used. \\
C1 & My note-taking follows a clear structure (e.g., main idea-supporting details-conclusion structure). \\
C2 & I often predict what the teacher is going to say based on the information I have heard so far. \\
C3 & I rely upon background knowledge to assist my comprehension of the text. \\
C4 & I often make a mental summary by incorporating different parts that I have heard. \\
C5 & I can deduce meanings of unfamiliar words in this practice; so I will never get stuck at certain parts of it. \\
C6 & I understand text on a word-by-word basis. \\
A1 & I encourage myself to cope with difficulties encountered in lecture listening (unfamiliar technical terms). \\
S1 & I interact with the teachers and peer students in order to clearly address my queries. \\
& ME=metacognitive strategies; C=cognitive strategies; A=affective strategies; S=social strategies
\end{tabular}

\section{ANALYSIS}

Reliability of the Questionnaire

Of the returned questionnaires, 4 questionnaires were discarded as invalid, as they were not filled in all the items completely.

The questionnaire scale ratings of the participants were entered into SPSS 17.0 for reliability analysis. Fortunately, overall reliability was demonstrated by Cronbach's alpha and the figure remained acceptable at .726 level. The reliability of the sub-sections in the questionnaire could be further improved upon, as the exactness and appropriateness of translation from English to Chinese might have caused a loss of the original meaning.

\section{RESUlts}

Correlation Analysis of Classroom-based Motivation in L2 Academic Listening and Listening Strategies

As shown in Table 4, most of the strategies correlate positively with task novelty (M6), among which the correlations between strategies and "attention" $(\mathrm{r}=.386, \mathrm{p}<0.01)$ and "self-encouragement" $(\mathrm{r}=.296, \mathrm{p}<0.01)$ in the classroom-based motivation constructs turned out to be significant. The results mean that the more novel a listening task, the more attention and self-encouragement the learner will have to complete it.

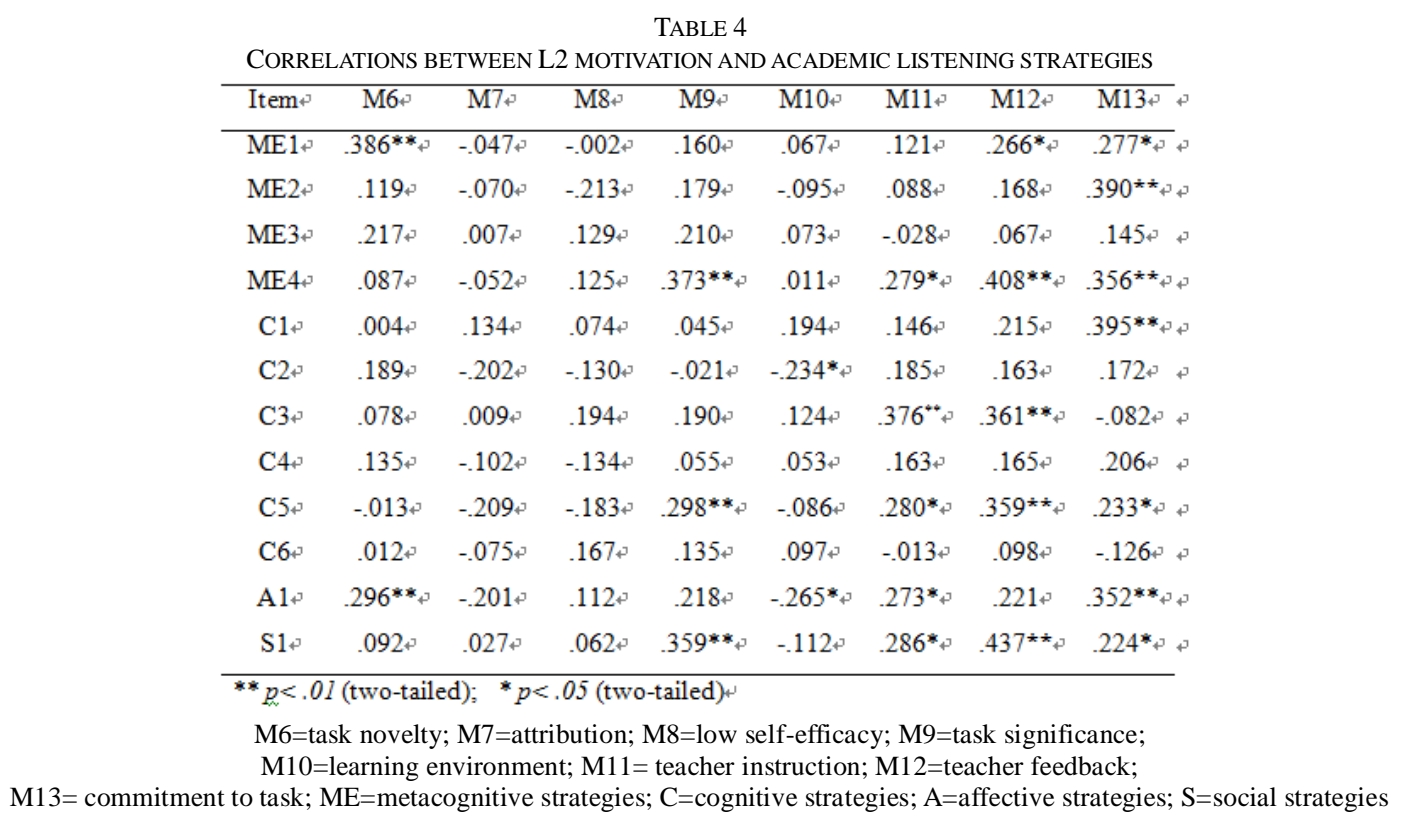

Moreover, it is clear that there are no correlations between attribution, self-efficacy and metacognitive strategies, cognitive strategies, or social/affective strategies. For instance, attribution (M7) correlates negatively with the majority of the strategies, such as attention ( $\mathrm{r}=-.047, \mathrm{n}=79)$, pre-planning $(\mathrm{r}=-.070, \mathrm{n}=79)$, recall $(\mathrm{r}=-.052$, $\mathrm{n}=79)$, inference $(\mathrm{r}=-.202, \mathrm{n}=79)$, summary $(\mathrm{r}=-.102, \mathrm{n}=79)$, guessing $(\mathrm{r}=-.209, \mathrm{n}=79)$, word-by-word comprehension $(\mathrm{r}=-.075)$, and self-encouragement $(\mathrm{r}=-.201, \mathrm{n}=79)$. In addition, as the item low self-efficacy is negatively worded, weak correlations can be seen with monitoring $(\mathrm{r}=.129, \mathrm{n}=79)$, recall $(\mathrm{r}=.125, \mathrm{n}=79)$, note-taking $(\mathrm{r}=.074, \mathrm{n}=79)$, reliance on background knowledge $(\mathrm{r}=.194, \mathrm{n}=79)$, word-by-word translation $(\mathrm{r}=.167, \mathrm{n}=79)$, and self-encouragement $(\mathrm{r}=.112, \mathrm{n}=79)$, and interaction $(\mathrm{r}=.062, \mathrm{n}=79)$ 
As indicated in Table 4, task significance (M9) is closely related to the listening strategies of recall $(\mathrm{r}=.373, \mathrm{p}<0.01)$, guessing $(r=.298, p<0.01)$, and after-class interaction $(r=.359, p<0.01)$. Other components such as goal-commitment are also found to strongly correlate with pre-planning $(\mathrm{r}=.390, \mathrm{p}<0.01)$, recall $(\mathrm{r}=.356, \mathrm{p}<0.01)$, note-taking ( $\mathrm{r}=.395$, $\mathrm{p}<0.01)$, and self-encouragement $(\mathrm{r}=.352, \mathrm{p}<0.01)$.

As for the classroom learning environment (M10), it should be noted that this item is negatively narrated and weak correlations between the learning environment and inference ( $r=-.234, p<0.05)$, as well as self-encouragement $(r=-.265$, $\mathrm{p}<0.05)$ were displayed. In contrast, both teacher instruction and teacher feedback correlated strongly with background knowledge $(\mathrm{r}=.376, \mathrm{r}=.361, \mathrm{p}<0.01)$. This means that the more a teacher presents background knowledge and provides feedback after students have applied it during a practice, the more students will be likely to use background knowledge again later. In addition, there was a significant correlation between teacher feedback and the strategies of recall ( $\mathrm{r}=.408)$, guessing $(\mathrm{r}=.359)$, and after-class interactions $(\mathrm{r}=.437)$ at the 0.01 level. At the 0.05 level, teacher instruction demonstrates a relatively higher degree of correlations with recall $(\mathrm{r}=.279)$, guessing $(\mathrm{r}=.280)$, self-encouragement $(\mathrm{r}=$. 273), and interaction after class $(r=.286)$. The more teachers' instructional actions motivate listeners, the greater the tendency that students will put the strategies of recall, self-encouragement, and after-class interactions into use.

\section{DisCUSSION}

\section{A. Discussion of Research Findings}

Evidently, learners' motivation is related to the role of teachers in terms of teacher instruction (M11). Teacher feedback (M12) significantly correlates with social strategies in addition to other strategies such as recall, reliance on background knowledge, and guessing as shown in Table 4. Such results were supported by the facts that giving regulatory feedback in strategy instruction, helping students to regulate their activities, and giving direct teaching to focus the learners' attention on the strategy being taught (William M. \& Burden R., 2001) are all beneficial to improve students' strategy use. Also, as indicated in Table 4, commitment to task (M13) correlates significantly with such metacognitive strategies as attention, pre-planning, and recall The result was consistent with the findings that students will be more actively involved in planning, organizing, and evaluating their own learning if they are equipped with a strong desire to achieve their goals (Okada et al., 1996).

Moreover, there are no apparent correlations between attribution (M7) and academic listening strategies. The result may be attributed to the fact that few students used previously unsuccessful study experiences to account for their current academic listening performance, even when their instructors did not comment positively on their performances in the lecture listening practice. Since listening is a one-off practice, the materials are entirely different each time. As a result, students do not care as much about their learning (listening) experience during this process.

Low self-efficacy (M8) is found to be inversely related to academic listening strategies. The result suggests that students tended to maximize their control over the demanding listening practice, in that they were driven by the intense pressure from mid-term and final listening tests. An additional reason is that the listening material was played several times. Even if the questions were beyond their listening ability during the first play through, they would gradually find ways to cope with the practice after listening for the second or third time. However, the results do not show any relationship can be predicted between low self-efficacy and the use of strategies. A study conducted by Yeldham (2009) among Taiwanese EFL learners supported the finding that strategy instruction would improve learners' self-efficacy in listening comprehension. Graham (2011) in her recent study also concluded that self-efficacy in listening can be enhanced through explicit strategy training.

Finally, no theoretical or empirical underpinnings led to the prediction of a close relationship between task significance and listening strategies, such as guessing $(\mathrm{r}=.298, \mathrm{p} \leq .01, \mathrm{n}=79)$ and after-class interactions $(\mathrm{r}=.359, \mathrm{p} \leq .01$, $\mathrm{n}=79$ ). The correlation was incidentally found to be statistically significant, and in this sense, obtaining such relationships in this study is significant for further exploration. This is because researchers did not previously know whether correlations between task significance and guessing, and after-class interaction existed.

\section{B. Pedagogical Implications}

The findings based upon the empirical study indeed shed light on a novel approach for strategy training in L2 listening. First, success of strategy instruction, as claimed by Dornyei (2010), is dependent on regulatory feedback. Second, learners are motivated or demotivated by how a teacher presents an activity, and how a teacher works and interacts with learners during completion of an activity (William and Burden, 2000). From a social constructivist perspective, an individual's motivation is related to social and contextual influences, such as "significant other people" and the "individual's interaction with these people" (William and Burden, 2001, p.121). Consequently, creating an engaging and stress-free learning environment, where rich feedback is available and instruction is engaging and stress-free, is of vital importance to improve classroom practice.

Additionally, more than giving feedback and creating a supportive learning environment, an individual's perception towards the significance of learning activities could arouse motivation. Learners have the tendency to analyse a specific learning task in order to see whether it is related to them personally, or to use Gardner and Lambert's (1972) term "intergratively" or "instrumentally". As such, different perceptions then decide different strategy use. Accordingly, what a language teacher could develop is a "learner-strategy approach" (Flowerdew and Miller, 2005, p.16). This approach 
encourages decision-making based upon the students' awareness of particular learning task, rather than being entirely dependent upon language teachers during the process of motivation formation and strategy choice. In listening comprehension instructions, teachers should help students identify which types of strategies are effective considering their motivations. For instance, learners who are strongly motivated to study abroad may be encouraged to summarize and reflect upon the use of strategies after practice and then the teacher should remind students to transfer strategy knowledge in the future. For example, taking language test such as TOEFL or IELTS, or attending lectures in native English speaking countries. In contrast, when competing with expert listeners in stressful standardised tests or practices, strategies that rely on background knowledge, would be more effective to lesser motivated students that demonstrate poor decoding skills, but who still try to achieve an equal understanding the whole lecture.

Based on the quantitative findings, a skill-developing listening course design is proposed (see Figure 1). In this model of course design, the teacher could prepare listening materials that are stimulating and personally significant to the listeners, enabling students to be highly motivated be involved in the listening process. The notion is consistent with the strong correlation between listening task novelty and attention, as well as with metacognitive strategies suggested in the Table 4 (sees M6 and ME1 in Table 4). According to Dekeyser (2007), besides stimulating content, a good practice involving real operating conditions as soon as possible can make knowledge related to learning skills smoothly proceduralized. This requires, the materials chosen to be practiced, if they need to be carefully revised as well, and should include the required tactics that are in accordance with mastery of the target skills. For instance, students are expected to be trained to identify and make use of the discourse markers (e.g., the most important, first, second) in well-adapted academic listening material involving many exercises.

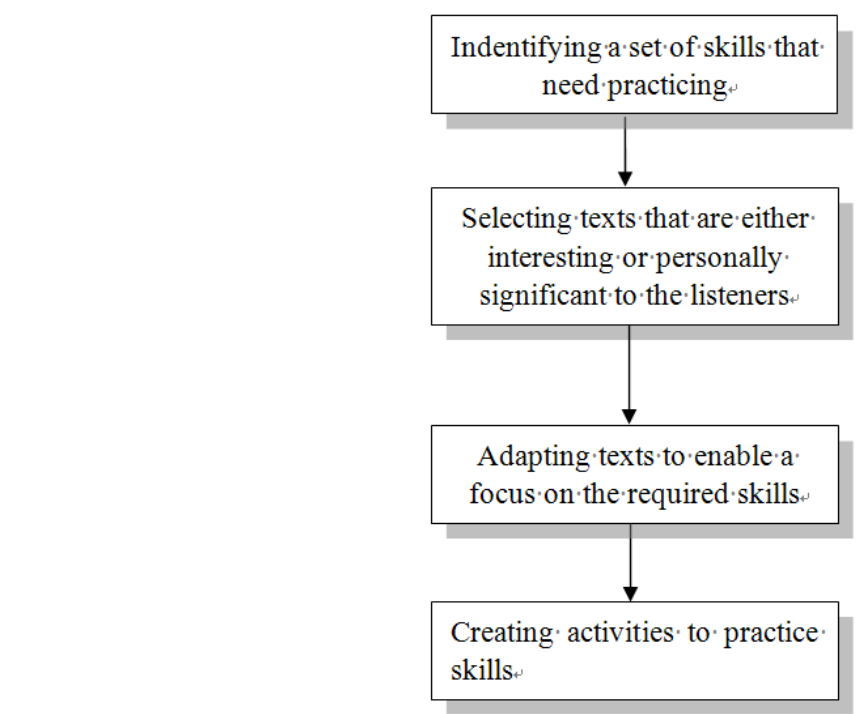

Figure 1: Procedure of a skill-developing, listening course design. Adapted from "A learning-centred approach," by T. Hutchinson and A. Waters, 1987, English for Specific Purpose, p.91.

\section{CONCLUSIONS}

Unfortunately, some limitations exist in this research. Firstly, a TOEFL test of a science topic was used to find out the students' academic listening proficiency. The students may be motivated differently and use different strategies in response to listening materials of different academic disciplines. Furthermore, due to the constraints of time, the study was not longitudinal in nature and did not keep track of the students' performances in the academic listening practice over a period of time. Follow-up investigations are necessary in order to see if the length of time, and the frequency of being exposed to the same type of practice, may change either the students' listening strategy use or their motivation orientation.

The study explored the Chinese listeners' choice of academic listening strategies in relation to L2 motivation. The results suggest that the teacher's instruction and feedback, task significance, and learners' commitment significantly affected the listener's choice of academic listening strategies. Some unexpected results require further investigation, such as the correlations between motivation constructs such as task significance, and listening strategies such as guessing and interactions after class, were identified in learners' performances in academic listening practice in a Chinese language learning environment.

More importantly, the results shed some light upon the innovative pedagogical approach that can be applicable to EFL contexts with regard to L2 listening learning and instruction. Above all, an engaging and supportive learning environment should be created, that is, effective instructions are presented followed closely by the timely feedback on the students' performances, and encouragement to listeners with varied language proficiency to use listening strategies of personal significance and interest. Finally, a skill-developing course design is proposed to promote listeners' strategy 
use awareness by integrating their motivation orientations.

Notes

1 Goh's research defined "strategy" and "tactic" as two distinct concepts. The former being in a general sense, while the latter was specific action. This research will use the same distinction.

\section{ACKNOWLEDGEMENTS}

This work was supported by the National Undergraduate Innovation and Entrepreneurship Training Programme (grant number 201210271063) led by Ministry of Education of the People's Republic of China. I would like to express sincere gratitude to Dr.Wei Xu for her great supervision and support.

\section{REFERENCES}

[1] Bacon, S. (1992). The relationship between gender, comprehension, processing strategies and cognitive and affective response. The Modern Language Journal, 76, 160-178.

[2] Chang, C.-S. (2008). Listening strategies of L2 learners with varied test tasks. TESL Canada Journal, 25, 1-26.

[3] Dekeyser, R. (2007). Conclusion: The Future of Practice. In Dekeyser, R. Editor (Ed.), Practice in a Second Language: Perspectives from Applied Linguistics and Cognitive Psychology (pp. 287-304). Cambridge: Cambridge University Press.

[4] Dörnyei, Z. (1994). Motivation and motivating in the foreign language classroom. Modern Language Journal, 78, $273-284$.

[5] Dörnyei, Z. (2003). Attitudes, orientations, and motivations in Language Learning: Advances in Theory, Research, and Applications. Language Learning, 53, 3-32.

[6] Dörnyei, Z., \& Ushioda, E. (2010). Teaching and researching: motivation. Harlow: Pearson Education Limited.

[7] Dörnyei, Z. and Ushioda, E. (2012). Motivation. In Gass, S. \& Mackey, A. (Ed.), The Routledge handbook of second language acquisition (396-409). New York: Routledge.

[8] Flowerdew, J. (1994). Academic listening: research perspectives. Cambridge: Cambridge University Press.

[9] Flowerdew, J. and Miller, L. (2005). Second Language Listening: Theory and Practice. Cambridge: Cambridge University Press.

[10] Gardner, R., \& Lambert, W. (1972). Attitudes and Motivation in Second Language Learning. Rowley, Mass.: Newbury House.

[11] Goh, C. (1998). How ESL learners with different listening abilities use comprehension strategies and tactics. Language Teaching Research, 2(2), 124-147.

[12] Graham, S. J., Santos, D. and Vanderplank, R. (2010) Strategy clusters and sources of knowledge in French L2 listening comprehension. Innovation in Language Learning and Teaching, 4 (1). pp. 1-20.

[13] Graham, S. (2011). Self-efficacy and academic listening. Journal of English for Academic Purpose, 10, 113-117.

[14] Huang, J. (2005). Challenges of academic listening in English: Reports by Chinese students. College Student Journal, 39 , 553-570.

[15] Huang, J. (2006). English abilities for academic listening: How confident are Chinese students? College Student Journal, 40, 40-49.

[16] Hutchinson, T. \& Waters, A. (1987). English for specific purposes. Cambridge: Cambridge University Press.

[17] Lynch, T. (2010). Academic listening in the 21st century: Reviewing a decade of research. Journal of English for Academic Purpose, 2011, 10, 79-88.

[18] MacIntyre, Peter D. \& Noels, A. (1996). Using social-psychological variables to predict the use of language learning strategies. Foreign Language Annals, 29, 374-386.

[19] McGruddy, R. (1995). The effect of listening comprehension strategy training with advanced level ESL students (Doctoral dissertation). Available from ProQuest Dissertations and Theses Database. (UMI No. 9916234)

[20] O’Malley, J. M., \& Chamot, A. U. (1990). Learning strategies in second language acquisition. Cambridge: Cambridge University Press.

[21] Onoda, S. (2012). Self-regulation and its relation to motivation and proficiency (Doctoral dissertation). Available from ProQuest Dissertations and Theses Database. (UMI No. 3493926)

[22] Oxford, R., \& Nyikos, M. (1989). Variables affecting choice of language learning strategies by university students. Modern Language Journal, 73, 291-300.

[23] Richards, J.C. (1983). Listening comprehension: approach, design, procedure. TESOL Quarterly, 17, 219-39.

[24] Rost, M. (2002). Teaching and researching listening. US: Pearson Education Limited.

[25] Rost, M. (1990). Listening in Language Learning. Harlow: Longman.

[26] Rubin, J. (1994). A review of second language listening comprehension research. The Modern Language Journal 78, $199-216$.

[27] Ushioda, E. (2010). Motivation and SLA: Bridging the gap. EUROSLA 12, 5-20.

[28] Vandergrift, L. (2003). Orchestrating strategy use: Toward a model of the skilled second language listener. Language Learning, 53, 463-496.

[29] Vandergrift, L. (2005). Relationships among motivation orientations, metacognitive awareness and proficiency in L2 listening. Applied Linguistics, 26, 70-89.

[30] Williams M., \& Burden, R.L. (1997). Psychology for language teachers (A social constructivist approach). Cambridge: Cambridge University Press.

[31] $\mathrm{Xu}, \mathrm{X}$. Y. (2011). The relationship between language learning motivation and the choice of language learning strategies among Chinese graduates. International Journal of English Linguistics, 1, 203-212.

[32] Yeldham, M. A. (2009). Approaches to second language listening instruction: Investigating the top-down/bottom-up debate. Unpublished doctoral dissertation, Australia: University of Melbourne.

[33] Yu, X. M. (2012). An empirical study on the correlation between English learning motivation and strategy. Asian Social Science, $8,218-22$. 
Bixi Jin is currently a second-year PhD candidate at the Faculty of Education, University of Hong Kong. Her research interests include second language motivation, academic writing, and corpus analysis. Her recent work appeared in Asian ESP journal.

Wei Xu is an Associate Professor at the School of Education, Shanghai International Studies University in China. Her research interests focuses on teacher education and development, learning strategies, and metacognition. She has published two articles in Creative Education in 2012 and 2013. 